\section{ZEW}

Zentrum für Europäische Wirtschaftsforschung GmbH

Centre for European Economic Research

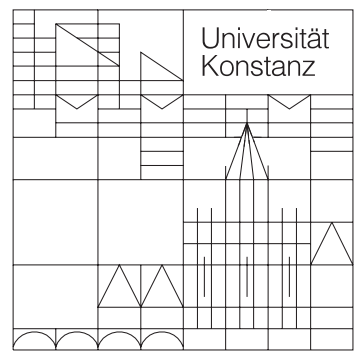

Rechts-, Wirtschafts- und Verwaltungswissenschaftliche Sektion Fachbereich

Wirtschaftswissenschaften

Diskussionspapiere der DFG-

Forschergruppe (Nr.: 3468269275):

Heterogene Arbeit: Positive und Normative Aspekte der Qualifikationsstruktur der Arbeit

Sandro Maffei,

Nikolai Raabe,

Heinrich W. Ursprung

Political Repression and Child Labor: Theory and Empirical Evidence

September 2004 
Diskussionspapier der Forschergruppe (Nr.: 3468269275) "Heterogene Arbeit: Positive und Normative Aspekte der Qualifikationsstruktur der Arbeit"

Nr. 04/19, September 2004

\section{Political Repression and Child Labor: Theory and Empirical Evidence}

\section{Sandro Maffei}

Fach D 138

Universität Konstanz

78457 Konstanz

Germany

mail: smaffei@t-online.de
Nikolai Raabe

Sternstraße 50,

40479 Düsseldorf

Germany

mail : nr4444@yahoo.de
Heinrich W. Ursprung

\author{
Fach D 138 \\ Universität Konstanz \\ 78457 Konstanz \\ Germany \\ mail :heinrich.ursprung@uni-konstanz.de
}

\section{Zusammenfassung:}

Most normative studies on child labor arrive at the conclusion that child labor is detrimental to social welfare. Child labor is, however, still prevalent in many developing countries even though in many of these countries it is forbidden by law. In this paper we develop a political-economic model that explains lenient enforcement of existing child labor legislation. The most important implication of our model is that in countries with repressive political regimes enforcement is more lenient and child labor thus more prevalent than in countries enjoying political freedom. We test this implication and find that it is confirmed by the data.

\footnotetext{
JEL Klassifikation : : D72, K14

Schlüsselwörter : child labor, political economy, freedom

Download/Reference : http://www.wiwi.uni-konstanz.de/forschergruppewiwil
} 


\title{
Political Repression and Child Labor: Theory and Empirical Evidence*
}

\author{
by \\ Sandro Maffei \\ Nikolai Raabe \\ Heinrich W. Ursprung** \\ Department of Economics \\ University of Konstanz
}

August 2004

\begin{abstract}
Most normative studies on child labor arrive at the conclusion that child labor is detrimental to social welfare. Child labor is, however, still prevalent in many developing countries even though in many of these countries it is forbidden by law. In this paper we develop a political-economic model that explains lenient enforcement of existing child labor legislation. The most important implication of our model is that in countries with repressive political regimes enforcement is more lenient and child labor thus more prevalent than in countries enjoying political freedom. We test this implication and find that it is confirmed by the data.
\end{abstract}

JEL classification: D 72, K 14

Keywords: child labor, political economy, freedom

* The authors thank Jan-Egbert Sturm for helpful comments.

** corresponding author: Department of Economics, University of Konstanz, Box D-138, 78457 Konstanz, Germany; e-mail: Heinrich.Ursprung@uni-konstanz.de; phone/fax: ++49 753188 


\section{Introduction}

The phenomenon of child labor is widespread in the developing world. Recent investigations carried out by the ILO's Bureau of Statistics estimate that in the developing countries at least 120 million children between 5 and 15 are working full time, and more than twice as many (or about 250 millions) work on a part-time basis. This is so even though child labor is illegal in 115 countries including many developing countries of Latin America and Africa where child labor is especially widespread (see ILO, 2002).

The observed prevalence of child labor appears to contradict recent theoretical findings that indicate that child labor is likely to reduce social welfare [see, for example, Ranjan (1999), Baland and Robinson (2000) and Dessy and Pallage (2001)]. Why do governments not combat child labor with more zeal? Why do they not punish parents who are observed to send their children to work more severely? In this paper we develop a political-economic model that explains this puzzle. Our explanation is based on the idea that the educated elite or their children may suffer an income loss if the number of educated people increases. If the educated elite has more political power than the uneducated masses, the political process may well give rise to a lenient enforcement of restrictive child labor legislations. Identifying the political power of the educated upper class with oligarchic political repression, we thus hypothesize that the prevalence of child labor resulting from the endogenous leniency of law enforcement varies positively with the degree of repression of the political system.

The political economy of child labor policy is still pretty much a white spot on the map of the economic research agenda. The normative literature on child labor, however, is by now quite well developed and covers various aspects of child labor [cf. 
Basu (1999)]. One of them is the supply of child labor. Rosenzweig (1981) and Goldin (1979), for example, apply a static neo-classical approach in which parents decide, among other things, how the time of their children is allocated between school and work. This approach is extended by Parsons and Goldin (1979) and Cigno (2000) who adopt a dynamic view. Gupta (2000) does not assume price taking households but uses the concept of Nash bargaining instead: parents and employers bilaterally negotiate the wages of the children. Another strand of the literature analyses the impact of child labor on social welfare and derives conditions that justify government interventions. Basu and Van (1998), Basu (1999) and Dessy (2000) show that labor markets may exhibit multiple equilibria with a ,good“ equilibrium in which children do not work and a „bad“" one in which child labor exists. They argue that a ban on child labor (Basu and Van) or compulsory education (Basu, Dessy) may jolt an economy from the „bad“ to the ,good“ equilibrium. According to Bell and Gersbach (2001), a better way to accomplish this transition may be a tax-transfer-program that taxes the rich households during the transition. Baland and Robinson (2000) consider capital market imperfections and show how borrowing constraints can give rise to child labor. Moreover, they show that even a soft constraint on child labor, i.e. a regulation which reduces the time children are allowed to work, may result in a significant Pareto improvement. Ranjan (1999) proposes to overcome capital market imperfections either by introducing a functioning credit market or by providing financial support for poor families. Dessy and Pallage (2001) argue that child labor may be the result of a coordination failure between parents who decide whether to invest in the human capital of their children and firms that decide whether to invest in skill based technology. Also in this case, a ban on child labor will result in a Pareto improvement. 
None of these models, however, gives an answer to the question why child labor still exists in many developing countries. Put differently: Why do governments in developing countries not always choose the most efficient policy to combat child labor? In a recent paper Shelburne (2001) moves toward the analysis of this puzzle. Shelburne analyses the stakes of the factor owners and identifies the gainers and losers from child labor. Making use of a standard Heckscher-Ohlin model with two goods and two factors (capital and labor, but skilled and unskilled labor would do just as well), he shows that in a closed economy the originally employed factors gain collectively from instituting child labor, whereas in a small open economy none of the original factors experiences a change in welfare from the addition of child workers. Based on these overall welfare effects Shelburne hypothesizes that economies open to international trade are less likely to suffer from child labor. He then goes on to show that this hypothesis cannot be rejected by a cross-country regression including 103 countries.

Shelburne himself is quite aware that his study does not really qualify as a fully fledged political-economic theory because of his model's focus on the overall effects on the non-child-labor factors. In his model capital unambiguously gains and labor loses from child labor in a closed economy. The reason is that child labor increases the relative labor endowment thereby decreasing the wage rate and increasing the capital rental. In a small open economy, on the other hand, the factor price equalization mechanism is at work, implying that child labor incidence has no effect on factor remuneration. A political economy model would therefore assume the capitalists to have more political power than the workers and then argue that increased openness to international trade reduces the capitalists' stake in soft child labor policies. Moreover, notice that the economic consequences of child labor that are analyzed in Shelburne's model derive exclusively from the endowment effect, i.e. from the fact that child labor 
increases a country's endowment with the factor labor. Even though this effect might well be sizable - Shelburne (p. 326) mentions estimates of over ten per cent of the labor force in some developing countries - a static analysis cannot capture the consequences of the arguably much more significant long-run losses associated with the fact that child labor always implies a loss in human capital investment.

In this paper we show how the political economy and the human capital aspect can be integrated in a model extending Shelburne's imaginative analysis. We thus firmly base our portrait of the political process on the political economy view and focus on the $d y$ namic consequences of child labor, i.e. on the trade-off between current and future disposable income in a model that allows human capital formation via education. ${ }^{1}$ In section 2, we outline our model. We assume that parents are not able to borrow money to finance the education of their children. If the government is inactive, child labor thus prevails in our economy due to imperfect capital markets. We then go on to show that imposing a penalty for sending children to work would decrease the incidence of child labor and increase the share of educated workers. A social welfare motivated government would thus set the most efficient penalty, i.e. the highest penalty which is legally possible. Child labor policy is endogenized in section 3. We show in particular that more repressive political regimes adopt a more lenient enforcement of child labor

\footnotetext{
${ }^{1}$ In order to focus on the dynamic effects, we neglect the static endowment effect of child labor. In this sense our analysis complements Shelburne's study.
} 
legislation which translates into a higher incidence of child labor. ${ }^{2}$ In section 4 we test this hypothesis using a panel data set covering 103 developing economies.

\section{The model of the economy}

We consider a closed economy with overlapping generations. Individuals live for three periods. In the first period they are children, in the second they become adults who work, give birth to a child and decide whether to send this child to school or to work. At the end of the second period of the parents' life, the children leave home and the parents keep on working in the third period in which no decisions are made. The only relevant private decision the individuals make during their whole life is whether to send their children to school or to work.

There are thus two types of adult individuals or workers: educated and uneducated ones. Each worker's labor supply is exogenous and normalized to unity; income therefore corresponds to the wage rate. The income $y_{t i}^{u}$ of an uneducated or unskilled adult worker $\mathrm{i}$ in period $\mathrm{t}$ and the income $y_{t j}^{s}$ of a educated or skilled adult worker $\mathrm{j}$ in period $t$ depends on the prevailing share $\omega_{\mathrm{t}}$ of skilled workers in the economy and the individual worker's ability $b_{i}$ or $b_{j}$. We use the following specification: ${ }^{3}$

\footnotetext{
${ }^{2}$ We thus focus in this paper on political repression, i.e. the absence of political free-
} dom. For various studies of economic freedom see the special volume of the European Journal of Political Economy edited and introduced by de Haan (2003).

3 The specification of the equations (1) is based on a microfoundation employed by Owen and Weil (1998, p.75-76) who assume an aggregate production function $Y=F(K, L)$, where the aggregate labor input $\mathrm{L}$ is a function of uneducated and educated 
$y_{t i}^{u}=b_{i}\left(a_{u}+q_{u} \omega_{t}\right)$ and $y_{t j}^{s}=b_{j}\left(a_{s}-q_{s} \omega_{t}\right)$, where $a_{s}>a_{u}>0$ and $q_{s}, q_{u}>0$.

The income $y_{t i}^{u}$ of an unskilled parent increases with the share $\omega_{t}$ of skilled workers, while the opposite holds for the income $y_{t j}^{s}$ of a skilled parent since a higher share $\omega_{t}$ of educated individuals directly translates in a higher supply of skilled relative to unskilled labor.

Children's abilities are assumed to be independent of their parent's ability; they are uniformly distributed over the support [1,2]. Moreover, we assume that $\left(a_{s}-q_{s}\right)>\left(a_{u}\right.$ $+\mathrm{q}_{\mathrm{u}}$ ), implying that if a skilled worker has the same ability as an unskilled worker, the skilled worker will always receive a higher income than the unskilled one.

Parents are not able to borrow money for the education of their children. If parent $m$ sends her child to work, she receives the following utility in the first period of her adult life:

(2) $U_{1 m}^{\text {work }}=\ln \left(y_{1 m}^{k}+y_{c}\right)-E-\pi p, \quad(k=u, s)$,

labor input in efficiency units: $\mathrm{L}=\mathrm{L}(\mathrm{U}, \mathrm{E})$. Factors are paid their marginal products. The economy is assumed to be open to the world capital market so that the world interest rate $r=F_{K}$ and the marginal product $F_{L}$ of a unit of aggregate labor will be constant. The wages (or incomes) per efficiency unit are then $\mathrm{y}_{U}=\mathrm{F}_{\mathrm{L}} \mathrm{L}_{\mathrm{U}}$ and $\mathrm{y}_{\mathrm{E}}=\mathrm{F}_{\mathrm{L}} \mathrm{L}_{\mathrm{E}}$ which implies via $\mathrm{U}=\mathrm{N}-\mathrm{E}$ that $\mathrm{y}_{\mathrm{U}}$ varies positively and $\mathrm{y}_{\mathrm{E}}$ varies negatively with the share $\mathrm{E} / \mathrm{N}$ of educated labor. In equation (1) we assume for analytical convenience a linear functional relationship between the incomes and the share of educated labor $\omega$ in the labor force. 
where $y_{c}$ is the income generated by a working child. Notice that $\mathrm{y}_{\mathrm{c}}$ as well as $y_{t i}^{u}$ in (1) do not depend on the number of children working because we suppress the "endowment effect" of child labor (see note 1). The exogenous variable $E$ denotes the emotional cost of sending one's child to work; this cost arises from violating a social norm denouncing child labor. ${ }^{4}$ Child labor is assumed to be illegal. The term $\pi p$ represents the expected costs of some kind of non-monetary punishment for violating the child labor laws; $\pi$ denotes the probability of detection and $p$ the cost of the imposed punishment.

If, on the other hand, parent $m$ sends her child to school, she receives the following utility:

$$
U_{1 m}^{\text {school }}=\ln \left(y_{1 m}^{k}-C\right),
$$

where $C$ represents schooling costs. Notice, that the specifications of (2) and (3) imply that no savings are made. This is in line with our assumption that functioning credit markets do not exist. Moreover, we assume that no transfers between adult children and parents take place because we do focus on traditional economic reasoning and not on altruistic motives which may be determined by class-specific cultures. The utility in the second period of adult life thus has the following appearance:

(4) $U_{2 m}=\ln \left(y_{2 m}^{k}\right)$.

The parents' decision whether to send their children to work or to school is based on a utility comparison. An unskilled parent $i$ sends her child to school, if

\footnotetext{
${ }^{4}$ Katav-Herz (2001) analyses a model in which $E$ varies negatively with the share of working children.
} 
$\Delta U_{i}^{u} \equiv U_{i u}^{\text {school }}-U_{i u}^{\text {work }}=\ln \left[b_{i}\left(a_{u}+\omega_{t} q_{u}\right)-C\right]-\ln \left[b_{i}\left(a_{u}+\omega_{t} q_{u}\right)+y_{c}\right]+E+\pi p \geq 0$

and a skilled parent $j$ sends her child to school, if

$\Delta U_{j}^{s} \equiv U_{j s}^{s c h o o l}-U_{j s}^{\text {work }}=\ln \left[b_{j}\left(a_{s}-\omega_{t} q_{s}\right)-C\right]-\ln \left[b_{j}\left(a_{s}-\omega_{t} q_{s}\right)+y_{c}\right]+E+\pi p \geq 0$

Since $\Delta U_{m}^{k}$ is increasing in the ability $b_{m},{ }^{5}$ it is the more able and thus richer parents in each of the two groups that send their children to school, the critical ability levels $b_{s}{ }^{*}$ and $b_{u}{ }^{*}$ for the skilled and unskilled amounting to

(7) $b_{s}^{*}=\frac{C+y_{c} e^{-E-\pi p}}{\left(a_{s}-q_{s} \omega_{t}\right)\left[1-e^{-E-\pi p}\right]} \quad$ and $\quad b_{u}^{*}=\frac{C+y_{c} e^{-E-\pi p}}{\left(a_{u}+q_{u} \omega_{t}\right)\left[1-e^{-E-\pi p}\right]}$.

Notice, that $\frac{\partial b_{s}^{*}}{\partial \omega_{t}}>0$ and $\frac{\partial b_{u}^{*}}{\partial \omega_{t}}<0$, i.e. as the share $\omega_{t}$ of skilled workers increases, more educated parents will have to send their children to work, whereas the converse is true for the uneducated ones. ${ }^{6}$ Moreover, it can easily be seen that the numerator of the expression in (7) decreases and the denominator increases with an increase of the penalty $\mathrm{p}$. Thus, we have $\frac{\partial b_{k}^{*}}{\partial p}<0$ for $\mathrm{k}=\mathrm{s}, \mathrm{u}$ : an increase in the penalty $\mathrm{p}$ will induce more parents to send their children to school.

${ }_{5} \frac{\partial \Delta U^{k}}{\partial b_{k}}=Y^{k} \frac{y_{d}{ }^{\text {work }}-y_{d}{ }^{\text {school }}}{y_{d}{ }^{\text {work }} y_{d}{ }^{\text {school }}}>0$, where the subscript d denotes disposable income and $Y^{u} \equiv\left(a_{u}+q_{u} \omega_{t}\right)$ and $Y^{s} \equiv\left(a_{s}-q_{s} \omega_{t}\right)$ "basic" income.

${ }^{6}$ To be sure, in an economy that exhibits positive externalities of education the negative effect of $\omega_{\mathrm{t}}$ on $b_{s}^{*}$ may be softened or even reversed. 
Let now $\mu_{t}$ denote the share of young skilled workers in the labor force in period $t$. Among these workers, those with an ability exceeding $b_{s}{ }^{*}$ send their children to school. The fraction of these workers amounts to $2-b_{s}^{*} .^{7}$ The share of young unskilled parents is $1-\mu_{t}$, and among these parents, those with an ability exceeding $b_{u}^{*}$ send their children to school. The fraction of these parents amounts to $2-b_{u}^{*}$. If $\delta_{t}$ denotes the share of children going to work, the share $1-\delta_{t}$ of children going to school then equals

$$
1-\delta_{t}=\mu_{t}\left(2-b_{s}^{*}\right)+\left(1-\mu_{t}\right)\left(2-b_{u}^{*}\right) .
$$

The share of children going to school today equals the share of skilled workers tomorrow; we thus have $1-\delta_{t}=\mu_{t+1}$. Since we assume a constant population (one child per parent), the share $\omega_{t}$ of skilled workers in the economy is simply the average of the share $\mu_{t}$ of young skilled workers and the share of old skilled workers (which in period t equals $\left.\mu_{t-1}\right): \omega_{t}=\frac{1}{2}\left(\mu_{t}+\mu_{t-1}\right)$. Substituting the critical skill levels given in (7) into equation (8) and observing that $1-\delta_{\mathrm{t}}=\mu_{\mathrm{t}+1}$ and $\omega_{t}=\frac{1}{2}\left(\mu_{t}+\mu_{t-1}\right)$, we receive the following dynamic system equation:

(9) $\mu_{t+1}=$

$$
\mu_{t}\left(2-\frac{C+y_{c} e^{-E-\pi p}}{\left(a_{s}-q_{s}\left(\frac{\mu_{t}+\mu_{t-1}}{2}\right)\right)\left(1-e^{-E-\pi p}\right)}\right)+\left(1-\mu_{t}\right)\left(2-\frac{C+y_{c} e^{-E-\pi p}}{\left(a_{u}+q_{u}\left(\frac{\mu_{t}+\mu_{t-1}}{2}\right)\left(1-e^{-E-\pi p}\right)\right.}\right) .
$$

\footnotetext{
${ }^{7}$ Notice, that the schooling decision of the parent is not based on the ability of the child. The ability distribution of the educated and uneducated adult population is therefore also uniform over the support $[1,2]$.
} 
We do not need to analyze the dynamic stability properties of this non-linear secondorder difference equation in detail. It suffices to show with the help of numerical examples that a large set of parameter constellations exist for which our dynamic system possesses a dynamically stable interior steady state $\mu^{*} \in(0,1)$, i.e. a steady state that exhibits coexistence of child labor and schooling. A representative example is provided in Appendix 1.

In a steady state, of course, the skill distribution does not vary across generations and we have

$1-\delta^{*}=\mu^{*}=\omega^{*}$.

That is, the steady state share of children attending school is equal to the share of old and young educated workers in the economy. The steady state can thus be characterized by the implicit function

(10) $F \equiv \mu^{*}-\mu^{*}\left(2-\frac{C+y_{c} e^{-E-\pi p}}{\left(a_{s}-q_{s} \mu^{*}\right)\left(1-e^{-E-\pi p}\right)}\right)-\left(1-\mu^{*}\right)\left(2-\frac{C+y_{c} e^{-E-\pi p}}{\left(a_{u}+q_{u} \mu^{*}\right)\left(1-e^{-E-\pi p}\right)}\right)=0$.

Dynamic stability of our system (9) requires that $\partial F / \partial \mu^{*}>0{ }^{8}$ Assuming dynamic stability we can proceed to derive from equation (10) via the correspondence principle our basic comparative static result:

(11) $\frac{\partial \mu^{*}}{\partial p}=-\frac{\partial F / \partial p}{\partial F / \partial \mu^{*}}=$ 
$\left[\mu^{*} \frac{\pi\left(y_{c}+C\right) e^{-E-\pi p}}{\left(a_{s}-q_{s} \mu^{*}\right)\left(1-e^{-E-\pi p}\right)^{2}}+\left(1-\mu^{*}\right) \frac{\pi\left(y_{c}+C\right) e^{-E-\pi p}}{\left(a_{u}+q_{u} \mu^{*}\right)\left(1-e^{-E-\pi p}\right)^{2}}\right] /(\partial F / \partial \mu *)>0$.

We thus have

\section{Proposition 1:}

A higher penalty p for sending children to work gives rise to an increase in the steady state value of the share of children attending school. In other words, a benevolent government is able to reduce the incidence of child labor by increasing the penalty $p$.

A numerical example provided in Appendix 1 shows the dynamic adjustment process that takes place after a permanent increase in $p$.

Since we observe in many developing countries lenient enforcement of the prohibition of child labor, we cannot portray government with the help of a social welfare maximizer. In the following section we therefore endogenize child labor policy by using a political support maximizing government. We thereby focus on one policy instrument, namely the penalty $\mathrm{p}$ for sending children to work.

${ }^{8}$ This follows from linearizing (9): $\mu_{t+1}-\frac{\partial \mu_{t+1}}{\partial \mu_{t}} \mu_{t}-\frac{\partial \mu_{t+1}}{\partial \mu_{t-1}} \mu_{t-1}=G$. Using the stability condition (cf. Gandolfo, 1997, p. 58) $1-\frac{\partial \mu_{t+1}}{\partial \mu_{t}}-\frac{\partial \mu_{t+1}}{\partial \mu_{t-1}}>0$ for the homogenous equation corresponding to (9) yields $\partial F / \partial \mu^{*}>0$ since $\frac{\partial b_{k}^{*}}{\partial \mu^{*}}=2 \frac{\partial b_{k}^{*}}{\partial \mu_{t}}=2 \frac{\partial b_{k}^{*}}{\partial \mu_{t-1}}$ for $\mathrm{k}=\mathrm{u}, \mathrm{s}$. 


\section{Endogenous Child Labor Policy}

We assume that the political decision concerning the severity of the penalty for sending children to work takes place in the beginning of a period, i.e. before the workers decide whether to send their children to work or to school. In order to identify the interests of the different groups, we examine how $p$ - the severity of the penalty - influences the utility of the different groups in the population. The only politically active age group that is affected and therefore influences the political determination of the penalty are the young adults. The political decision influences the young adults through their next-period wages since a higher penalty results in more parents sending their children to school in period $t$ which, in turn, implies that the share of skilled workers increases in period $\mathrm{t}+1$. As a consequence the skilled workers' wages fall and the unskilled workers' wages rise in $t+1$. In addition to this wage effect, the utility of the parents sending their children to work in period $t$ decreases because they potentially suffer a larger penalty for sending their children to work.

Summed up, an increase in $p$ has two effects: a first period direct penalty effect which negatively affects the parents who send their children to work, and a second period indirect income effect which is positive for all young unskilled workers and negative for all young skilled workers. Notice, that the old adults have no stake in the political decision because the income effect materializes only after they have retired and the penalty affects only parents of children who are subject to compulsory schooling. Clearly, the young skilled workers unambiguously lose from a higher penalty and the resulting lower incidence of child labor, whereas the young unskilled workers gain if we assume that the income effect on the poorest of the unskilled workers (i.e. those who send their children to work) dominates the penalty effect. One might argue that under these 
circumstances the unskilled parents could simply coordinate their behavior, i.e. they could agree to send their children to work even if the government deserts the interests of the poor and does not enforce the existing child labor laws. The uneducated masses are, however, caught in a Prisoners' Dilemma situation and cannot enforce their agreement without an outside agency such as the police.

Drawing on the seminal work of Stigler (1971) and Peltzman (1976), we portray the political process with the help of a political support maximizing government. The utility of the educated upper class enters the political support function with a weight of $\alpha$, whereas the utility of the uneducated masses enters with the weight $1-\alpha$. The exogenously given parameter $\alpha$ measures the degree of political repression of the uneducated masses by the oligarchy of the educated elite. If $\alpha$ is close to unity, the government closely follows a policy advocated by the elite. If, on the other hand, $\alpha$ is close to zero, the uneducated masses constitute a "dictatorship of the proletariat." A true democracy would give each citizen the same weight; in this case $\alpha$ would be equal to the population share of the educated citizens in our model.

To be more specific, we use the following political support function of the government:

$M(p)=(1-\alpha)\left[\int_{1}^{b_{u}{ }^{*}} U_{i u}^{\text {work }} d b_{i}+\int_{b_{u}{ }^{*}}^{2} U_{i u}^{\text {school }} d b_{i}\right]+\alpha\left[\int_{1}^{b_{s}{ }^{*}} U_{j s}^{\text {work }} d b_{j}+\int_{b_{s}{ }^{*}}^{2} U_{j s}^{\text {school }} d b_{j}\right]$.

The first terms on the RHS in (12) measures the welfare of the young unskilled workers who send their children to work and to school, respectively. The interest of the uneducated masses enters the political support function with the weight 1- $\alpha$. The second term measures the welfare of the young skilled workers sending their children to work 
and to school, respectively. The interest of the educated elite enters the political support function with the weight $\alpha$.

We assume now that the political-economic system is in a steady state whenever a policy decision with respect to the penalty level $\mathrm{p}$ is made. The idea behind this rather innocent assumption is that this kind of policy is only infrequently revised so that the system will in the meantime arrive at a state close to the long-run equilibrium. We thus proceed from an initial equilibrium exhibiting child labor $\left(1-\delta^{*}=\mu^{*}=\omega^{*}<1\right)$, and a penalty level $\mathrm{p}$ that is set such that political support $\mathrm{M}$ is at a maximum. If the political system now becomes more repressive, i.e. more responsive to the interests of the educated elite ( $\alpha$ increases), this will give rise to an endogenous policy adjustment described in our

\section{Proposition 2:}

Starting out from a steady state, an increase in political repression, i.e. an increase in the parameter $\alpha$, will decrease the penalty $p$ for parents who are detected to send their children to work: $\frac{\partial p}{\partial \alpha}<0$. As a consequence the incidence of child labor will, of course, increase.

The proof of Proposition 2 is in Appendix 2. 


\section{Political repression and child labor: Empirical evidence}

In this section we test the hypothesis (expressed in Proposition 2) that political repression, ceteris paribus, increases the incidence of child labor. In the developed countries, to be sure, child labor is negligible; this is why the international institutions that are concerned with the phenomenon of child labor focus their attention on the developing countries. We therefore do not include the developed countries (that all enjoy political freedom) in our sample; doing so would also bias the estimation results in favor of our hypothesis. $^{9}$

Moreover, our hypothesis does not relate to countries which have had or still have a communist regime; these countries, even though they did or still do exhibit a great deal of political repression, cannot be portrayed as an oligarchy of an educated elite. In the communist systems children were generally considered to represent the new generation of socialist men and women who would be in a position to build the communist society that was supposed to loom on the horizon. For this declared objective (and maybe also for the politically more tangible objective of indoctrination in order to stabilize the regime) the communist governments followed a long-run education policy in which schooling of the masses played an important role. In any event, child labor is

\footnotetext{
${ }^{9}$ Rated as developed countries are only those countries that were already developed in 1970, the beginning of our panel. Our sample includes, however, countries that reached the status of a developed country after 1970 such as the European country Turkey, the OPEC countries, South Korea etc. A complete list of the countries included in our sample is to be found in Appendix 2.
} 
not an issue in a true communist system. We therefore do not include these countries in our sample either.

After having excluded developed and (formerly) communist countries, data availability allows us to build a panel with a maximum of 103 countries for the years 1970, 1980, 1990, 1995, 1998, 2000 and 2002.

For our empirical test we need, first of all, data on child labor incidence and on political repression. Moreover, theoretical considerations and previous empirical work suggest the inclusion of several control variables. The variables that we employed in our regressions are described below.

\subsection{Data description}

Our endogenous variable child labor incidence (CHILDLABOR) is defined as the share of children (between 10 and 14 years) who are active in the labor force. Labor force activity is defined as working for wage or salary (in cash or in kind) for at least 1 hour during the reference period. We use the data set compiled by the ILO which is available from the World Bank Indicators. Like all official data on child labor, also this data set is likely to suffer from underreporting. These inevitable problems notwithstanding, the ILO data has the advantage of being compatible with the internationally accepted definitions; they are therefore suitable for cross-country comparisons (cf. Ashagrie, 1993).

With respect to the explanatory variables, the economic literature clearly stipulates that family income is the single most important household level determinant of child labor. Following the empirical literature, we use GDP per capita (GDP). 
As a proxy variable measuring the absence of capital market imperfections Dehejia and Gatti (2002) use the ratio of domestic credit extended to the private sector and GDP (CREDIT). For lack of a better measure we also use this variable even though we are well aware that in developing countries many self-help institutions have developed in the shadow economy that provide substitutes for official bank loans (cf. Montiel et al., 1993).

Cigno (2000) empirically investigates the influence of the number of children per family on the parents' decision whether to send their children to work or to school and finds a positive effect. We also tried this determinant of child labor and use as our proxy variable the share of the children up to age 14 in the population (CHILDREN). The CHILDREN variable captures an economic effect (working through income per family member) as well as some socio-economic effect emanating from the generally perceived role of the family. A second socio-economic variable that is likely to influence child labor incidence is the degree of urbanization of a given society. We use the share of a country's population living in an urban environment (URBAN) to capture the respective effect on the child labor market. While children in the rural sector are mainly employed in agricultural activities such as cattle herding, in urban areas children are mainly employed in the trade, production and service sectors. Although urban child labor is more in the limelight of the media, the percentage of working children is, according to new estimates (see ILO, 2002), twice as high in rural areas.

In our empirical study we test two major political-economic hypotheses. The first one has been emphasized by Shelburne (2001) who argues that an open economy will, ceteris paribus, be less prone to child labor, because general education has no adverse effects on the wage rate of the skilled workers if the factor price equalization mechanism 
of international trade is at work. An alternative route of influence would be that open economies are more inclined to enforce their child labor legislation in order to avoid trade sanctions. We measure the openness of an economy by using the standard approach which associates openness with the ratio of exports plus imports and GDP (TRADE). ${ }^{10}$ The second political-economic hypothesis is the one we developed in the previous sections: child labor incidence increases as the political system becomes more repressive. We measure political repression with the help of the Political Rights Index of Freedomhouse (POLREPR). Since its inception in the 1970s the Freedom in the World Survey has provided an annual evaluation of political rights and civil liberties throughout the world. ${ }^{11}$ The Survey measures freedom in all countries and territories by using a single standard; it ranks the covered countries and territories on the basis of observed government-induced restrictions of liberty rather than on policy platforms or legislation. The Political Rights Index employs criteria such as „Is the head of state and/or head of government or other chief authority elected through free and fair elections?, or „Are the people free from domination by the military, foreign powers, totalitarian parties, religious hierarchies, economic oligarchies, or any other powerful groups?" (cf. Freedomhouse, 2003). The higher the value of the POLREPR index the more repressive is the political system.

Apart from these major political-economic hypotheses we test three more hypotheses that also have some political-economic flair. Shelburne (2001, p. 368) advanced the hypothesis that the larger a country (assuming that it is not completely closed), the

\footnotetext{
10 This measure is not uncontroversial. Bretschger and Hettich (2002), for example, argue that the foreign trade share should be adjusted for country size.

${ }^{11}$ As there are no Values for 1970, the Values of 1972 have been used instead.
} 
more likely child labor is to reduce the welfare of the non-child-labor factors, and thus the less likely is the practice of child labor in the economy. We use a dummy variable for small countries (SMALLCTR) to capture this potential effect. Moreover, it suggests itself to include foreign aid (AID) and foreign direct investments (FDI) received in order to check whether these flows (both measured as a share of GDP) are targeted at countries that are in line with the political outlook of the donor or host countries.

In some regressions we include dummy variables that capture the countries' geography, predominant religion, natural resources, and whether the country has adopted international conventions dealing with child labor standards.

\subsection{Econometric implementation and results}

Like Gatti and Dehejia (2002) we estimate an OLS and a Tobit specification of our regression equation. Since child labor incidence cannot be negative and in a considerable number of countries included in our sample child labor incidence is negligible, our data set of the endogenous variable is left censored. OLS thus might not be appropriate in this context. The Tobit specification accounts for the mass point in the distribution of the endogenous variable and reacts, moreover, less sensitive to outliers; the Tobit specification therefore appears to be more appropriate. Since, however, only about 13 percent of our child labor data points assume the value zero, the OLS estimates should not differ too much from the Tobit estimates; we thus use the OLS estimates as a robustness check.

Our empirical analysis employs the following baseline specification:

(17) CHILDLABOR $_{\text {it }}=\alpha+\beta_{1}$ LNGDP $_{\text {it }}+\beta_{2}$ CREDIT $_{\text {it }}+\beta_{3}$ URBAN $_{\text {it }}+\beta_{4}$ TRADE $_{i t}+$ $\beta_{5}$ POLREPR $_{\text {it }}+\varepsilon_{\text {it }}$ 
Notice, that the income variable LNGDP is the logarithmic transform of the original variable GDP.

The OLS results are reported in table 1 and the Tobit results in table 2 . In a first regression we only include the economic explanatory variables LNGDP and CREDIT. In column 2 the influence of the socio-economic variable URBAN is added. The political-economic variables TRADE and POLREPR are, finally, included in column 3.

As we expected, the results reported in tables 1 and 2 are quite similar; the Tobit estimates do have, however, a slightly higher adjusted R-squared. The estimates presented in the first columns indicate that a large part of the variance in child labor incidence across countries and over time can be explained by economic factors. As expected, a higher income and easier access to private loans gives rise to a lower child labor incidence. The socio-economic variable URBAN, which we include in the second columns, also turns out to exert a significant influence on child labor. Child labor incidence is significantly lower in urban environments. In the third columns we test the political-economic hypotheses. Both political-economic variables included have a statistically significant influence on the prevalence of child labor. As our hypothesis suggests, political repression has a positive effect on child labor incidence. Openness to international trade is also significant and has the anticipated negative sign.

In order to make our estimates more comparable with other empirical studies we show in column 4 of table 2 the results of our baseline Tobit estimation (table 2, column 3 ) when the industrial countries are included in the sample. Our base-line result remains unaltered. 


\subsection{Sensitivity Analysis}

To check for robustness of our results presented in tables 1 and 2, we have included additional explanatory variables in our baseline regression. The results are summarized in tables 3 and 4.

The regressions presented in table 3 extend our baseline regression (table 2, column 3 ) by adding various dummy variables. In column 1 we test whether Islamic countries do have a significantly different incidence of child labor from other countries. Since nearly all of the OPEC countries are Islamic, ${ }^{12}$ we also have included an OPEC dummy to control for the effect of oil-related affluence. The Islamic dummy is negative but not quite significant at the $10 \%$ level; the OPEC countries, however, clearly have, ceteris paribus, a significantly lower child labor incidence. Notice that the POLREPR variable's impact is not altered by the inclusion of these additional explanatory variables. Thus, although most OPEC countries are ruled by rather autocratic regimes, these countries are characterized by a relatively low incidence of child labor. In these countries oil is the most important source of income, and a part of this source of government income is probably used to implement budgetary policies that combat child labor, partly, maybe, in order to stabilize the established political order. On the other hand, it is questionable whether Islamic countries in general exhibit any special characteristics with respect to child labor even though one may have conjectured that the "book-based" Islamic culture and the fact that the female labor participation rate is traditionally very low in Islamic countries would give rise to a relatively low child labor incidence. Also notice that the income variable LNGDP is not significantly affected by the inclusion of the OPEC dummy.

\footnotetext{
12 The only exception is Venezuela.
} 
In all the following estimates we retain the OPEC dummy since the incidence of child labor evidently is reduced by oil-related affluence. In column 2 of table 3 we add continent dummies. The dummy for the sub-Saharan countries is positive and highly significant. This could be interpreted to imply that in these countries specific cultural factors are at work which account for an additional child labor incidence of about ten percentage points. Since many African countries have rather repressive political regimes, it is perhaps surprising that this collinearity does not appear to greatly influence the estimate of our crucial political-economic variable POLREPR which retains significance at the standard $1 \%$ level. Notice, however, that the estimate of the coefficient of the CREDIT variable is substantially reduced and is not significant anymore even at the $5 \%$ level (the p-statistic is 0.056 ). To be sure, the socio-economic substance of the continent dummies is quite elusive; these variables serve well as robustness tests but do not convey much information about the determinants of child labor. We therefore decided not even to retain the SUBSAHARA dummy whose coefficient is clearly different from the other continent dummies in our further robustness tests. To show that this strategy does not affect our final result, we will however return to the continent dummies in our last regression.

In column 3 of table 3 we check whether countries with a population under one million are special. The variable SMALLCTRY is not significant and has no substantial effect on the other variables. Unlike Shelburne (2001) we thus cannot find any empirical support for his hypothesis. In column 4 we include a dummy for the countries that ratified the ILO resolution 138 against child labor. Just as the dummy variable SMALLCTRY the ILO138 dummy does not have an immediate statistically significant influence on child labor incidence either. The international promise to take meas- 
ures against child labor thus does not have an Immediate influence on actual policies. Again, notice that the estimates for our crucial variable POLREPR are not affected by the inclusion of these additional variables.

In table 4 we first include variables capturing capital inflows. In column 1 we add foreign direct investments as an explanatory variable to our baseline regression. The FDI coefficient is positive but statistically by no means significant. ${ }^{13}$ The number of included observations is substantially smaller in this regression as compared to the baseline regression since the FDI (and AID) data are not available for all countries in our sample and are not yet available for the year 2002 in general. The baseline results are however not affected by this reduction of sample size. In column 2 we add foreign aid (AID). Because of the smaller sample size the z-values are somewhat reduced, the main exceptions being TRADE and POLREPR (the corresponding estimate without AID is shown in column 3). AID varies positively with CHILDLABOR and this effect is significant at the $1 \%$ level. This result is also interesting from a normative point of view since it indicates that while foreign aid for humanitarian reasons may be a legitimate response to an observed high incidence of child labor, a policy measure that is likely to help to cure the evil would be to allow the developing countries full access to the world market.

In column 4 we introduce the explanatory variable CHILDREN that measures family size. The variable indeed has the predicted positive coefficient and is highly significant: a large number of children reduces the disposable family income per household member and thus makes parents more inclined to send their children to work. The in-

\footnotetext{
${ }^{13}$ On the relationship between political repression and FDI see Harms and Ursprung (2002) or Busse (2003).
} 
clusion of this variable is, however, not unproblematic from an econometric point of view. First, it appears possible that family size depends on the admissibility of child labor since in a society that is predisposed to tolerate child labor, poor parents have an additional incentive to produce offspring. Moreover, the variable CHILDREN is highly correlated with the variable POLREPR. The combined effect of the exogeneity and the collinearity problems does however not appear to have any dramatic influence on our results even though it may responsible for the slight drop in significance of our pet variable POLREPR. Notice also that for obvious reasons the family-size variable CHILDREN which is supposed to capture the effect if income per family member somewhat reduces the size of the coefficient of the original income variable LNGDP. The last regression in column 5 is identical to the previous regression with the exception that it also includes the continent dummies (not shown) ${ }^{14}$ that we have already used above (cf. table 3, column 2). The inclusion of the continent dummies reduces the estimated coefficients of the variables CREDIT (as in regression 2, table 3) and AID whose coefficients are not significantly different from zero anymore. The influence on the political-economic variables TRADE and POLREPR is, however, very modest.

Summed up, we arrive at the conclusion that our robustness check supports the hypothesis that political repression gives, ceteris paribus, rise to a higher child labor incidence in developing countries.

\footnotetext{
${ }^{14}$ The coefficients of the continent dummies ASIA, NORTHAFR and LATINAM are again not significantly different from zero, whereas the coefficient of SUBSAHARA amounts to 9.08 and is with a z-statistic of 4.27 significant at the $1 \%$ level.
} 


\section{Conclusion}

Even though child labor is forbidden by law in most developing countries, child labor is still widespread in the third world. We developed in this paper a political-economic model that explains lenient enforcement of existing child labor legislation. Assuming a closed-economy overlapping-generations model with skilled and unskilled workers, we show that autocratic governments dominated by well-educated elites have no incentive to strictly enforce any child labor regulations since doing so would increase the supply of skilled labor with detrimental effects on the wage rate of the ruling elites' clans. This argument gives rise to the empirically testable hypothesis that the prevalence of child labor is, ceteris paribus, the higher the more the government is dominated by such autocratic elites.

To test this hypothesis, we use a panel data set of 103 developing countries for seven years between 1970 and 2002. Based on previous empirical investigations of child labor, we add a variable which measures the degree of political repression in a country as a proxy for the degree of autocratic government capture by educated elites. Our results are in accordance with the conclusion of previous empirical studies with respect to the standard explanatory variables of child labor incidence. The political repression variable turns out to have a significant impact on the incidence of child labor as predicted by the model. To check our results' robustness, we carried out both OLS and a Tobit estimations and we examined whether our results remain stable when nonstandard explanatory variables are included. The two estimation techniques and the various specifications of the estimation equation have no significant influence on our baseline estimates. We are thus confident in concluding that a policy of supporting any moves towards political liberalization is also helpful in combating child labor. 


\section{Appendix 1: Numerical example of the dynamic adjustment following an in-}

\section{crease in the penalty $p$}

Consider the following numerical values of the model's parameters: $C=0, E=0.1, y_{c}=$ $0.2266, \pi=0.5, \mathrm{p}=0.1, \mathrm{a}_{\mathrm{S}}=1.2, \mathrm{a}_{\mathrm{u}}=0.8$, and $\mathrm{q}_{\mathrm{s}}=\mathrm{q}_{\mathrm{u}}=0.1$. It is straight forward to show that $\mu=\omega=1-\delta=0.620148$ defines the steady state of the dynamic system: if $\omega=0.62$ ( $62 \%$ of the labor force is skilled) then (see equations 7$) b_{u}^{*}=1.62$ (i.e. the poorest $62 \%$ of the unskilled workers send their children to work) and $b_{s}^{*}=1.23$ (i.e. the poorest $23 \%$ of the skilled workers send their children to work). Thus, the share $1-\delta$ of children going to school amounts to $1-\delta=(0.62)(2-1.23)+(1-0.62)(2-1.62)=0.62$ which shows that the share of skilled workers will also be 0.62 in the next generation.

Starting out from this steady state we now increase in period 1 the penalty $\mathrm{p}$ from $\mathrm{p}_{0}=0.1$ to $\bar{p}=0.15$ and leave it there for all following periods. The following table shows how the critical values $b_{u}^{*}$ and $b_{s}^{*}$, the shares of the skilled work force, and the share of children going to school changes in the course of the adjustment process.

The direct penalty effect decreases in the first period the share of parents who send their children to work: $b_{s}^{*}$ and $b_{u}^{*}$ become smaller. This increases in the second period and thereafter the share of skilled workers: $\mu$, and with a time lag, $\omega$ increase. The indirect wage effect further decreases the share of uneducated parents sending their children to work ( $b_{u}^{*}$ continues to decrease) whereas it increases the share of educated parents who do so ( $b_{s}^{*}$ increases after $\mathrm{t}=1$ ). The effect on the behavior of the uneducated parents is however stronger than the effect of the educated parents so that the aggregate wage effect is still favorable ( $\mu$ and $\omega$ continuously increase). After a few 
periods the system is close to the new steady state in which the share of educated individuals is much higher than in the original steady state (91\% as compared to $62 \%)$.

\begin{tabular}{|c|c|c|c|c|c|}
\hline & $\mu$ & $b_{s}^{*}$ & $b_{u}^{*}$ & $1-\delta$ & \\
\hline $\mathrm{t}=0$ & 0.620148 & 1,230244 & 1.624102 & 0.620148 & 0.620148 \\
\hline $\mathrm{t}=1$ & 0.620148 & 1.041191 & 1.374524 & 0.832192 & 0.620148 \\
\hline $\mathrm{t}=2$ & 0.832192 & 1.050983 & 1.357824 & 0.897527 & 0.726170 \\
\hline $\mathrm{t}=3$ & 0.897527 & 1.064073 & 1.336581 & 0.908002 & 0.864860 \\
\hline $\mathrm{t}=4$ & 0.908002 & 1.067707 & 1.330890 & 0.908080 & 0.902765 \\
\hline $\mathrm{t}=5$ & 0.908080 & 1.068215 & 1.330102 & 0.907712 & 0.908041 \\
\hline $\mathrm{t}=6$ & 0.907712 & 1.068201 & 1.330123 & 0.907626 & 0.907896 \\
\hline $\mathrm{t} \rightarrow \infty$ & 0.907623 & 1.068175 & 1.330164 & 0.907623 & 0.907623 \\
& & & & & \\
\hline
\end{tabular}

\section{Appendix 2: $\quad$ Proof of Proposition 2}

Let $\mathrm{M}_{\mathrm{u}}(\mathrm{p})$ denote the political support provided by the unskilled voters. That is,

$$
\frac{M_{u}(p)}{1-\alpha}=\int_{1}^{b_{u}^{*}(p)}\left\{\ln \left(b_{i} \bar{Y}_{1}^{u}+y_{c}\right)-E-\pi p\right\} d b_{i}+\int_{b_{u}^{*}(p)}^{2}\left\{\ln \left(b_{i} \bar{Y}_{1}^{u}-C\right)\right\} d b_{i}+\int_{1}^{2}\left\{\ln \left(b_{i} Y_{2}^{u}(\omega(p))\right)\right\} d b_{i}
$$

where $\bar{Y}_{1}^{u} \equiv a_{u}+q_{u} \bar{\omega}_{1}$ and $Y_{2}^{u} \equiv a_{u}+q_{u} \omega_{2}(p)$ denote "basic" income in period 1 and 2 , respectively (see also note 4). The first (second) term on the RHS of the above equation is the contemporaneous (or period 1) utility of the unskilled voters who send their 
children to work (school) and the third term is the utility of all unskilled voters in the next period. Integrating yields

$$
\begin{aligned}
& \frac{M_{u}(p)}{1-\alpha}=\left[\left(\frac{b_{i} \bar{Y}_{1}^{u}+y_{c}}{\bar{Y}_{1}^{u}}\right)\left(\ln \left(b_{i} \bar{Y}_{1}^{u}+y_{c}\right)-1\right)-(E+\pi p) b_{i}\right]_{1}^{b_{u}^{*}(p)}+ \\
& \quad\left[\left(\frac{b_{i} \bar{Y}_{1}^{u}-C}{\bar{Y}_{1}^{u}}\right)\left(\ln \left(b_{i} \bar{Y}_{1}^{u}-C\right)-1\right)\right]_{b_{u}^{*}(p)}^{2}+\left[b_{i}\left(\ln \left(b_{i} Y_{2}^{u}(\omega(p))\right)-1\right)\right]_{1}^{2} \\
& =\left(\frac{b_{u}^{*}(p) \bar{Y}_{1}^{u}+y_{c}}{\bar{Y}_{1}^{u}}\right)\left(\ln \left(b_{u}^{*}(p) \bar{Y}_{1}^{u}-y_{c}\right)-1\right)-(E+\pi p) b_{u}^{*}(p)-K_{1}+\pi p+K_{2} \\
& \quad-\left(\frac{b_{u}^{*}(p) \bar{Y}_{1}^{u}-C}{\bar{Y}_{1}^{u}}\right)\left(\ln \left(b_{u}^{*}(p) \bar{Y}_{1}^{u}-C\right)-1\right)+2\left(\ln \left(2 Y_{2}^{u}(\omega(p))\right)-1\right)-\left(\ln Y_{2}^{u}(\omega(p))-1\right)
\end{aligned}
$$

where $\mathrm{K}_{1}$ and $\mathrm{K}_{2}$ denote terms that do not depend on the parameter $\mathrm{p}$.

Differentiating with respect to $p$ yields

$$
\begin{gathered}
\frac{\partial}{\partial p} \frac{M_{u}(p)}{1-\alpha}=\frac{\partial b_{u}^{*}}{\partial p}\left(\ln \left(b_{u}^{*} \bar{Y}_{1}^{u}+y_{c}\right)-1\right)+\frac{1}{\bar{Y}_{1}^{u}} \frac{b_{u}^{*} \bar{Y}_{1}^{u}+y_{c}}{b_{u}^{*} \bar{Y}_{1}^{u}+y_{c}} \frac{\partial b_{u}^{*}}{\partial p}-\frac{\partial b_{u}^{*}}{\partial p}(E+\pi p)-\pi b_{u}^{*}+\pi \\
-\frac{\partial b_{u}^{*}}{\partial p}\left(\ln \left(b_{u}^{*} \bar{Y}_{1}^{u}-C\right)-1\right)-\frac{1}{\bar{Y}_{1}^{u}} \frac{b_{u}^{*} \bar{Y}_{1}^{u}-C}{b_{u}^{*} \bar{Y}_{1}^{u}-C} \bar{Y}_{1}^{u} \frac{\partial b_{u}^{*}}{\partial p}+2 \frac{2 \frac{\partial Y_{2}^{u}}{\partial \omega} \frac{\partial \omega}{\partial p}}{2 Y_{2}^{u}}-\frac{\frac{\partial Y_{2}^{u}}{\partial \omega} \frac{\partial \omega}{\partial p}}{Y_{2}^{u}} \\
=\frac{\partial b_{u}^{*}}{\partial p}\left(\ln \left(b_{u}^{*} \bar{Y}_{1}^{u}+y_{c}\right)-E-\pi p\right)+\left(1-b_{u}^{*}\right) \pi-\frac{\partial b_{u}^{*}}{\partial p} \ln \left(b_{u}^{*} \bar{Y}_{1}^{u}-C\right)+\frac{\partial Y_{2}^{u}}{\partial \omega} \frac{\partial \omega}{\partial p} \frac{1}{Y_{2}^{u}} .
\end{gathered}
$$

Since $\ln \left(b_{u}^{*} \bar{Y}_{1}^{u}+y_{c}\right)-E-\pi p=y_{\text {work }}^{u}\left(b_{u}^{*}\right), \ln \left(b_{u}^{*} \bar{Y}_{1}^{u}-C\right)=y_{\text {school }}^{u}\left(b_{u}^{*}\right)$ and $y_{\text {work }}^{u}\left(b_{u}^{*}\right)=y_{\text {school }}^{u}\left(b_{u}^{*}\right)$ we arrive at

$$
\frac{\partial}{\partial p} \frac{M_{u}(p)}{1-\alpha}=\left(1-b_{u}^{*}\right) \pi+\frac{\partial Y_{2}^{u}}{\partial \omega} \frac{\partial \omega}{\partial p} \frac{1}{Y_{2}^{u}} \frac{\omega}{\omega}=\left(1-b_{u}^{*}\right) \pi+\varepsilon_{u} \frac{\partial \omega / \partial p}{\omega}
$$

where $\varepsilon_{u} \equiv \frac{\partial Y_{2}^{u}}{\partial \omega} \frac{\omega}{Y_{2}^{u}}$ denotes the "skilled-share" elasticity of "basic" income. 
For the skilled voters one obtains the symmetric expression

$$
\frac{\partial}{\partial p} \frac{M_{s}(p)}{\alpha}=\left(1-b_{s}^{*}\right) \pi+\varepsilon_{s} \frac{\partial \omega / \partial p}{\omega}
$$

The first-order condition of political support maximization thus has the following appearance:

$\frac{\partial M(p)}{\partial p}=(1-\alpha)\left(\left(1-b_{u}^{*}\right) \pi+\varepsilon_{u} \frac{\partial \omega / \partial p}{\omega}\right)+\alpha\left(\left(1-b_{s}^{*}\right) \pi+\varepsilon_{s} \frac{\partial \omega / \partial p}{\omega}\right)=0$.

Applying the implicit function rule finally yields

$$
\frac{\partial p}{\partial \alpha}=-\frac{\pi b_{u}^{*}-\pi b_{s}^{*}+\frac{\partial \omega / \partial p}{\omega}\left(\varepsilon_{s}-\varepsilon_{u}\right)}{\partial^{2} M / d p^{2}} .
$$

Since $\partial \omega / \partial p>0, \varepsilon_{u}>0, \varepsilon_{s}<0$, and the denominator is negative via the correspondence principle, all terms with the exception of $\pi b_{u}^{*}$ are negative. A sufficient (but by no means necessary) condition for $\frac{\partial p}{\partial \alpha}$ to be negative is that the poor unskilled voters (these are the unskilled voters who send their children to work) are in favor of a higher penalty because the short-run penalty effect is smaller than the long-run income effect. Since this is an assumption that we introduced previously, Proposition 2 holds. 


\section{Countries in the Sample}

\begin{tabular}{|c|c|c|c|c|}
\hline Africa & Asia & America & Oceania & Europe \\
\hline Algeria** & Bahrain & Argentina & Fiji & Turkey \\
\hline Angola* & Bangladesh & Bahamas & Papua New & \\
\hline Benin* & Bhutan & Barbados & Guinea & \\
\hline Botswana* & Cambodia & Belize & Solomon Isl. & \\
\hline Burkina Faso* & Inida & Bolivia & & \\
\hline Burundi* & Indonesia & Brazil & & \\
\hline Cameroon* & Iran & Chile & & \\
\hline Cape Verde* & Israeal & Colombia & & \\
\hline Chad* & Jordan & Costa Rica & & \\
\hline Comoros* & Korea, Rep. & Dominican Rep. & & \\
\hline Congo, Dem. Rep* & Kuwait & Ecuador & & \\
\hline Congo, Rep*. & Lao PDR & El Salvador & & \\
\hline Cote d'Ivoire* & Lebanon & Guatemala & & \\
\hline Egypt** & Malaysia & Guyana & & \\
\hline Equatorial Guinea* & Maldives & Haiti & & \\
\hline Eritrea* & Nepal & Honduras & & \\
\hline Ethiopia* & Oman & Jamaica & & \\
\hline Gabon* & Pakistan & Mexico & & \\
\hline Gambia* & Phillipines & Nicaragua & & \\
\hline Ghana* & Saudi Arabia & Panama & & \\
\hline Guinea* & Singapore & Paraguay & & \\
\hline Guinea-Bissau* & Sri Lanka & Peru & & \\
\hline Kenya* & Syria & Suriname & & \\
\hline Lesotho* & Thailand & Trinidad/Tobago & & \\
\hline Liberia* & United Arab Emirates & Uruguay & & \\
\hline Madagascar* & Yemen & Venezuela & & \\
\hline \multicolumn{5}{|l|}{ Malawi* } \\
\hline \multicolumn{5}{|l|}{ Mali* } \\
\hline \multicolumn{5}{|l|}{ Mauretania** } \\
\hline \multicolumn{5}{|l|}{ Mauritius* } \\
\hline \multicolumn{5}{|l|}{ Morocco** } \\
\hline \multicolumn{5}{|l|}{ Mozambique* } \\
\hline \multicolumn{5}{|l|}{ Namibia* } \\
\hline \multicolumn{5}{|l|}{ Niger* } \\
\hline \multicolumn{5}{|l|}{ Nigeria* } \\
\hline \multicolumn{5}{|l|}{ Rwanda* } \\
\hline \multicolumn{5}{|l|}{ Senegal* } \\
\hline \multicolumn{5}{|l|}{ Sierra Leone* } \\
\hline \multicolumn{5}{|l|}{ South Africa } \\
\hline \multicolumn{5}{|l|}{ Sudan** } \\
\hline \multicolumn{5}{|l|}{ Swaziland* } \\
\hline \multicolumn{5}{|l|}{ Tanzania* } \\
\hline \multicolumn{5}{|l|}{ Togo* } \\
\hline \multicolumn{5}{|l|}{ Tunisia** } \\
\hline \multicolumn{5}{|l|}{ Uganda* } \\
\hline \multicolumn{5}{|l|}{ Zambia* } \\
\hline Zimbabwe* & & & & \\
\hline
\end{tabular}


Table 1: OLS estimates

\begin{tabular}{|c|c|c|c|}
\hline OLS & (1) & (2) & (3) \\
\hline LNGDP & $\begin{array}{l}-8.689421 \\
(-23.65)^{\star \star}\end{array}$ & $\begin{array}{l}-5.140301 \\
(-9.92)^{\star \star}\end{array}$ & $\begin{array}{l}-4.335710 \\
(-7.65)^{\star \star}\end{array}$ \\
\hline CREDIT & $\begin{array}{l}-0.070171 \\
(-3.89)^{\star \star}\end{array}$ & $\begin{array}{l}-0.062591 \\
(-3.68)^{\star \star}\end{array}$ & $\begin{array}{l}-0.054704 \\
(-3.01)^{\star \star}\end{array}$ \\
\hline URBAN & & $\begin{array}{l}-0.249471 \\
(-9.34)^{\star *}\end{array}$ & $\begin{array}{l}-0.287019 \\
(-10.22)^{\star *}\end{array}$ \\
\hline TRADE & & & $\begin{array}{l}-0.053256 \\
(-5.16)^{\star \star}\end{array}$ \\
\hline POLREPR & & & $\begin{array}{l}0.813345 \\
(3.88)^{\star \star} \\
{[0.000]}\end{array}$ \\
\hline $\mathrm{C}$ & $\begin{array}{l}80.71194 \\
(34.17)^{\star \star}\end{array}$ & $\begin{array}{c}66.83670 \\
(24.71)^{\star \star}\end{array}$ & $\begin{array}{c}63.05790 \\
(19.27)^{\star \star}\end{array}$ \\
\hline Observations & 643 & 638 & 570 \\
\hline Ad. R-squared & 0.595790 & 0.642690 & 0.675785 \\
\hline
\end{tabular}

(t-statistic); [p-statistic]; ${ }^{*}$ ) significant at the $5 \%$ level; ${ }^{* *}$ ) significant at the $1 \%$ level

Table 2: Tobit estimates

\begin{tabular}{|c|c|c|c|c|}
\hline TOBIT & (1) & (2) & $\begin{array}{c}\text { baseline regression } \\
\text { (3) }\end{array}$ & (4) \# \\
\hline LNGDP & $\begin{array}{l}-10.04921 \\
\left(-24.30^{\star \star}\right.\end{array}$ & $\begin{array}{l}-5.828711 \\
(-10.51)^{\star \star}\end{array}$ & $\begin{array}{l}-4.946218 \\
(-8.15)^{\star \star}\end{array}$ & $\begin{array}{l}-4.641048 \\
(-9.03)^{\star \star}\end{array}$ \\
\hline CREDIT & $\begin{array}{l}-0.123478 \\
(-6.00)^{\star \star}\end{array}$ & $\begin{array}{l}-0.119802 \\
(-6.27)^{\star \star}\end{array}$ & $\begin{array}{l}-0.093304 \\
(-4.63)^{\star \star}\end{array}$ & $\begin{array}{l}-0.088445 \\
(-4.97)^{\star \star}\end{array}$ \\
\hline URBAN & & $\begin{array}{l}-0.299619 \\
(-10.49)^{\star \star}\end{array}$ & $\begin{array}{l}-0.338046 \\
(-11.19)^{\star \star}\end{array}$ & $\begin{array}{l}-0.335061 \\
(-12.22)^{\star \star}\end{array}$ \\
\hline TRADE & & & $\begin{array}{l}-0.063206 \\
(-5.65)^{\star \star}\end{array}$ & $\begin{array}{l}-0.066020 \\
(-6.51)^{\star \star}\end{array}$ \\
\hline POLREPR & & & $\begin{array}{l}0.571748 \\
(2.51)^{\star} \\
{[0.012]}\end{array}$ & $\begin{array}{l}0.483790 \\
(2.23)^{\star} \\
{[0.026]}\end{array}$ \\
\hline $\mathrm{C}$ & $\begin{array}{l}90.19559 \\
(33.88)^{\star \star}\end{array}$ & $\begin{array}{l}73.93009 \\
(25.31)^{\star \star}\end{array}$ & $\begin{array}{l}70.99577 \\
(19.88)^{\star \star}\end{array}$ & $\begin{array}{l}69.47592 \\
(21.56)^{\star \star}\end{array}$ \\
\hline Observations & 643 & 638 & 570 & 709 \\
\hline Ad. R-squared & 0.636794 & 0.697763 & 0.715170 & 0.769374 \\
\hline
\end{tabular}

(z-statistic); [p-statistic]; *) significant at the $5 \%$ level; **) significant at the $1 \%$ level

\# This regression includes also the following developed countries:: Australia, Austria, Belgium, Canada, Cyprus, Denmark, Finland, France, Germany, Greece, Ireland, Iceland, Italy, Japan, Luxembourg, Malta, Netherlands, New Zealand, Norway, Portugal, Spain, Sweden, Switzerland, United Kingdom, United States. 
Table 3: Robustness check 1

\begin{tabular}{|c|c|c|c|c|}
\hline Tobit & (1) & (2) & (3) & (4) \\
\hline LNGDP & $\begin{array}{l}-4.878824 \\
(-7.77)^{\star \star}\end{array}$ & $\begin{array}{l}-3.232843 \\
(-5.59)^{\star \star}\end{array}$ & $\begin{array}{l}-4.693385 \\
(-7.58)^{\star \star}\end{array}$ & $\begin{array}{l}-4.5821 \\
(-7.38)^{\star \star}\end{array}$ \\
\hline CREDIT & $\begin{array}{l}-0.093256 \\
(-4.59)^{\star \star}\end{array}$ & $\begin{array}{l}-0.036102 \\
(-1.91)\end{array}$ & $\begin{array}{l}-0.096523 \\
(-4.7)^{\star \star}\end{array}$ & $\begin{array}{l}-0.1000 \\
(-4.95)^{\star \star}\end{array}$ \\
\hline URBAN & $\begin{array}{r}-0.325081 \\
(-10.71)^{\star \star}\end{array}$ & $\begin{array}{l}-0.331677 \\
(-11.79)^{\star \star}\end{array}$ & $\begin{array}{l}-0.330558 \\
(-10.91)^{\star \star}\end{array}$ & $\begin{array}{l}-0.3357 * * \\
(-10.99)\end{array}$ \\
\hline TRADE & $\begin{array}{c}-0.065421 \\
(-5.89)^{\star \star}\end{array}$ & $\begin{array}{l}-0.087276 \\
(-8.48)^{\star \star}\end{array}$ & $\begin{array}{l}-0.067754 \\
(-5.51)^{* *}\end{array}$ & $\begin{array}{l}-0.0662 \\
(-5.91)^{\star \star}\end{array}$ \\
\hline POLREPR & $\begin{array}{l}0.798777 \\
(3.35)^{\star \star} \\
{[0.001]}\end{array}$ & $\begin{array}{l}0.675455 \\
(3.05)^{\star \star} \\
{[0.002]}\end{array}$ & $\begin{array}{l}0.713590 \\
(3.09)^{\star \star} \\
{[0.003]}\end{array}$ & $\begin{array}{l}0.719008 \\
(3.100694)^{\star *} \\
{[0.002]}\end{array}$ \\
\hline OPEC & $\begin{array}{l}-4.050270 \\
(-2.49)^{\star} \\
{[0.013]}\end{array}$ & $\begin{array}{l}-2.766970 \\
(-1.90) \\
{[0.057]}\end{array}$ & $\begin{array}{l}-4.688698 \\
(-2.99)^{\star \star}\end{array}$ & $\begin{array}{l}-4.725288 \\
(-3.01)^{\star \star}\end{array}$ \\
\hline \multirow[t]{2}{*}{ ISLAM } & -1.431190 & & & \\
\hline & $(-1.52)$ & & & \\
\hline \multirow[t]{2}{*}{ ASIA } & & -0.332350 & & \\
\hline & & $(-0.17)$ & & \\
\hline \multirow[t]{2}{*}{\begin{tabular}{|l} 
N-AFRICA \\
\end{tabular}} & & -0.843953 & & \\
\hline & & $(-0.36)$ & & \\
\hline SUBSAHARA & & $\begin{array}{l}10.57379 \\
(5.42)^{\star \star}\end{array}$ & & \\
\hline LATIN-AM & & $\begin{array}{l}2.904569 \\
(1.53)\end{array}$ & & \\
\hline \begin{tabular}{|l} 
SMALLCTRY \\
\end{tabular} & & & $\begin{array}{l}0.638731 \\
(0.44)\end{array}$ & \\
\hline ILO138 & & & & $\begin{array}{l}0.544882 \\
(0.57)\end{array}$ \\
\hline C & $\begin{array}{c}70.03431 \\
(18.90)^{\star *}\end{array}$ & $\begin{array}{l}54.09353 \\
(13.37)^{\star \star}\end{array}$ & $\begin{array}{l}69.07118 \\
(18.87)^{\star \star}\end{array}$ & $\begin{array}{l}68.41665 \\
(18.52)^{\star \star}\end{array}$ \\
\hline Observations & 570 & 570 & 570 & 570 \\
\hline Ad. R-squared & 0.720751 & 0.773320 & 0.720574 & 0.719847 \\
\hline
\end{tabular}

(z-statistic); [p-statistic]; *) significant at the 5\% level; $\left.{ }^{* *}\right)$ significant at the $1 \%$ level 
Table 4: Robustness check 2

\begin{tabular}{|c|c|c|c|c|c|}
\hline Tobit & (1) & (2) & (3) & (4) & (5)\# \\
\hline LNGDP & $\begin{array}{l}-5.0091 \\
(-7.20)^{\star \star}\end{array}$ & $\begin{array}{l}-3.6285 \\
(-5.03)^{\star \star}\end{array}$ & $\begin{array}{l}-4.6473 \\
(-7.62)^{\star \star}\end{array}$ & $\begin{array}{l}-2.9233 \\
(-4.05)^{\star \star}\end{array}$ & $\begin{array}{l}-2.211762 \\
(-3.26)^{\star \star}\end{array}$ \\
\hline CREDIT & $\begin{array}{c}-0.0863 \\
(-3.86)^{\star \star}\end{array}$ & $\begin{array}{l}-0-0916 \\
(-4.22)^{\star \star}\end{array}$ & $\begin{array}{l}-0.0985 \\
(-4.91)^{\star \star}\end{array}$ & $\begin{array}{l}-0.0610 \\
(-2.77)^{\star \star}\end{array}$ & $\begin{array}{l}-0.018302 \\
(-0.89)\end{array}$ \\
\hline URBAN & $\begin{array}{l}-0.3143 \\
(-9.26)^{\star \star}\end{array}$ & $\begin{array}{l}-0.3483 \\
(-10.89)^{\star \star}\end{array}$ & $\begin{array}{l}-0.3325 \\
(-11.08)^{\star \star}\end{array}$ & $\begin{array}{l}-0.3212 \\
(-10.07)^{\star \star}\end{array}$ & $\begin{array}{l}-0.319062 \\
(-10.48)^{\star \star}\end{array}$ \\
\hline TRADE & $\begin{array}{l}-0.0768 \\
(-5.94)^{\star \star}\end{array}$ & $\begin{array}{l}-0.0815 \\
(-6.76)^{\star \star}\end{array}$ & $\begin{array}{l}-0.0654 \\
(-5.89)^{\star \star}\end{array}$ & $\begin{array}{l}-0.0832 \\
(-7.02)^{\star \star}\end{array}$ & $\begin{array}{l}-0.098066 \\
(-8.89)^{\star \star}\end{array}$ \\
\hline POLREPR & $\begin{array}{l}0.7645 \\
(3.06)^{\star *} \\
{[0.002]}\end{array}$ & $\begin{array}{l}0.7921 \\
(3.28)^{\star \star} \\
{[0.001]}\end{array}$ & $\begin{array}{l}0.7060 \\
(3.06)^{\star \star} \\
{[0.002]}\end{array}$ & $\begin{array}{l}0.5481 \\
(2.26)^{\star} \\
{[0.024]}\end{array}$ & $\begin{array}{l}0.517222 \\
(2.19)^{\star} \\
{[0.029]}\end{array}$ \\
\hline OPEC & $\begin{array}{l}-5.3456 \\
(-3.08)^{\star *}\end{array}$ & $\begin{array}{l}-4.3823 \\
(-2.67)^{\star *}\end{array}$ & $\begin{array}{l}-4.7080 \\
(-3.00)^{\star \star}\end{array}$ & $\begin{array}{l}-5.1123 \\
(-3.17)^{\star \star}\end{array}$ & $\begin{array}{l}-3.456736 \\
(-2.27)^{\star}\end{array}$ \\
\hline FDI & $\begin{array}{l}0.0858 \\
(0.89)\end{array}$ & & & & \\
\hline AID & & $\begin{array}{c}0.143289 \\
(2.79)^{\star \star}\end{array}$ & & $\begin{array}{l}0.111360 \\
(2.20)^{\star}\end{array}$ & $\begin{array}{l}0.060148 \\
(1.29)\end{array}$ \\
\hline CHILDREN & & & & $\begin{array}{c}0.488345 \\
(4.98)^{\star \star}\end{array}$ & $\begin{array}{l}0.332084 \\
(3.69)^{\star \star}\end{array}$ \\
\hline$C$ & $\begin{array}{l}70.75023 \\
(17.21)^{\star \star}\end{array}$ & $\begin{array}{l}62.07897 \\
(13.88)^{\star \star}\end{array}$ & $\begin{array}{l}68.83233 \\
(19.00)^{\star \star}\end{array}$ & $\begin{array}{l}36.83613 \\
(5.52)^{\star \star}\end{array}$ & $\begin{array}{l}35.03447 \\
(5.38)^{\star \star}\end{array}$ \\
\hline Observations & 491 & 517 & 570 & 517 & 517 \\
\hline Ad. R-squared & 0.709649 & 0.726680 & 0.720397 & 0.736466 & 0.777157 \\
\hline
\end{tabular}

(z-statistic); [p-statistic]; *) significant at the $5 \%$ level; ${ }^{* *}$ ) significant at the $1 \%$ level

\# including continent dummies (not shown) 
Table 6: Data Sources

\begin{tabular}{|c|c|c|}
\hline Variable & Explanation & Source \\
\hline CHILDLABOR & $\begin{array}{l}\text { number of children aged 10-14 that active in the labor force divided by } \\
\text { the total number of children aged } 10-14\end{array}$ & WDI 2003 \\
\hline$(\mathrm{LN}) \mathrm{GDP}$ & (logarithm of) per capita GDP in constant U.S. dollars & WDI 2003 \\
\hline CREDIT & $\begin{array}{l}\text { volume of domestic bank credit extended to the private sector divided } \\
\text { by GDP }\end{array}$ & WDI 2003 \\
\hline URBAN & share of the total population living in urban & WDI 2003 \\
\hline TRADE & sum of exports and imports of goods and services divided by GDP & WDI 2003 \\
\hline POLREPR & Political Right Index & Freedomhouse 2003 \\
\hline ILO138 & 1 for countries which ratified the ILO convention 138 , otherwise 0 & ILOLEX 2003 \\
\hline SMALLCNTRY & 1 for countries which have a population below one million, otherwise 0 & WDI 2003 \\
\hline OPEC & 1 for members of OPEC, otherwise 0 & OPEC 2003 \\
\hline ISLAM & $\begin{array}{l}1 \text { for countries in which Islam is the predominant religion (largest reli- } \\
\text { gious group), otherwise } 0\end{array}$ & Fischer Weltalmanach \\
\hline CHILDREN & $\begin{array}{l}\text { number of children below the age of } 15 \text { years divided by total popula- } \\
\text { tion }\end{array}$ & WDI 2003 \\
\hline FDI & gross foreign direct investment inflow divided by GDP & WDI 2003 \\
\hline AID & $\begin{array}{l}\text { Sum of official development assistance and net official aid divided by } \\
\text { GDP }\end{array}$ & WDI 2003 \\
\hline
\end{tabular}




\section{References}

Ashagrie, K. (1993): "Statistics on Child Labor," Bulletin of Labor Statistics, 3. Geneva: International Labor Organization.

Baland, J.-M. and J. Robinson (2000): “Is Child Labor Inefficient?” Journal of Political Economy 108, 663-679.

Basu, K. and P.H. Van (1998): “The Economics of Child Labor,” American Economic Review $88,412-427$.

Basu, K. (1999): “Child Labor: Cause, Consequence and Cure, with Remarks on International Labor Standards," Journal of Economic Literature 37, 1083-1119.

Bell, C. and H. Gersbach (2001): "Child Labor and the Education of a Society," IZA Discussion Paper No. 338.

Bretschger, L. and F. Hettich (2002): “Globalization, capital mobility and tax competition: Theory and evidence for OECD countries, “European Journal of Political Economy 18, 695716.

Busse, M. (2003): “Democracy and FDI,” HWWA Discussion Paper No.220.

Cigno A. (2000): “Why do Indian Children work, and is it bad for them?” IZA Discussion Paper No. 115.

De Haan, J. (2003): Economic freedom: editor's introduction, European Journal of Political Economy 19, 395-403.

Dehejia, R. and D. Gatti (2002): “Child Labor: the Role of Income Variability and Access to Credit Across Countries," NBER working paper 9018 
Dessy, S. (2000): “A Defence of Compulsive Measures Against Child Labor,” Journal of Development Economics 62, 261-275.

Dessy, S. and S. Pallage (2001): “Child Labor and Coordination Failures," Journal of Development Economics 65, 469-476.

Fischer Weltalmanach (2003), Frankfurt, Fischer Verlag.

Freedomhouse (2003): http://www.freedomhouse.org

Goldin, C. (1979): "Household and Market Production of Families in a Late Nineteenth Century American City," Explorations in Economic History 16, 111-131.

Gupta, M. (2000): “Wage Determination of a Child Worker: A Theoretical Analysis," Review of Development Economics 4/2, 219-228.

Harms, P. and H. Ursprung (2002): "Do civil and political repression really boost foreign direct investment?" Economic Inquiry 40, 651-63.

ILO (2002): Every Child Counts: New Global Estimates on Child Labour, International Labour Office, Geneva April 2002.

ILOLEX (2003): Database on International Labor Standards, www.ilo.org/ilolex/ Katav-Herz, S. (2001): “Social Conformity and Child Labor,” Unpublished Paper. Montiel, P., P. Agenor and N. U1 Haque (1993): Informal Financial Markets in Developing Countries. A Macroeconomic Analysis, Blackwell, Oxford.

OPEC (2003): The official OPEC website, www.opec.org/homepage/frame.htm Owen, A. and D. Weil (1998): "International Earnings Mobility, Inequality and Growth," Journal of Monetary Economics 41, 71-104. 
Parsons, D. and C. Goldin (1989): "Parental Altruism and Self Interest: Child Labor among Late Nineteenth-Century American Families,” Economic Inquiry 27, 637-659.

Peltzman, S. (1976): “Towards a More General Theory of Regulation,” Journal of Law and Economics 19, 211-240.

Ranjan, P. (1999): “An Economic Analysis of Child Labor,” Economics Letters 64, 99-103. Rosenzweig, M. (1981): “Household and Non-Household Activities of Youths: Issues of Modelling, Data and Estimation Strategies," in G. Rodgers and G. Standing (eds.): Child work, Poverty and Underdevelopment. Geneva (ILO), 215-243.

Shelburne, R. (2001): “An Explanation of the International Variation in the Prevalence of Child Labor," The World Economy 24, 359-378.

Stigler, G. (1971): “The Theory of Economic Regulation,” Bell Journal of Economics and Management Science 2, 3-21.

WDI (2003): World Development Indicators, www.worldbank.org/data/wdi2003/index.htm 